\title{
Albanian EU Integration and its Economic Convergence in the Agricultural Sector
}

\author{
Arjola Mitaj \\ "Eqrem Cabej" University, Gjirokaster, Albania
}

a mitaj@yahoo.com

Jonida Avdulaj

"Eqrem Cabej" University, Gjirokaster, Albania

jonidaqendro@hotmail.com

Klodian Muco

"Eqrem Cabej" University, Gjirokaster, Albania

klodian.muco@uninsubria.it

\section{Abstract}

Recently, the core of political and economic debate in Albania consists on reflections related to increasing the Albanian competitiveness in international markets. Fiscal pressures, low labor costs in the Albanian market and the attraction of foreign investment during the last years seems to have not yielded the expected results, not only for being more competitive in foreign markets but even for domestic consumption. It is mentioned here domestic consumption because focused on agricultural sector, it can be considered as a strategic sector of the future in Albania, and especially the EU where we aspire to take part, requests from Albania to orient production toward agriculture. This sector although constitutes 22\% of GDP and occupies $47 \%$ of total employees fulfills only a quarter of domestic consumption (INSTAT, 2013). The impact of this sector in EU countries is only $1.7 \%$. These indicators are simple enough to understand that even though agriculture is the most important sector of the country, from the standpoint of employment and the strategies remains still one of the sectors with the lowest productivity in Europe and shows that our country in order to achieve EU levels, has a lot of work to do and it is very essential for this process taking in consideration or paying attention to the "best practices" of this sector to reduce the gap created between Albania and the EU countries if we truly aspire to become part of this family. It is often discussed about the stimulation of foreign enterprises to displace a part of their manufacturing in our country. Or more precisely, it has often been demanded that foreign enterprises should operate in traditional sectors with output compartments that use a non-specialized labor intensive. According to modern economic theories, low labor cost is one of the primary factors in the international fragmentation of production (Lucas, 1988; Stokey, 1991; Bassanini and Scarpetta (2002b). While talking about labor cost, this should not be confused with low salaries, because not always a low salary coincides with a low labor cost. The problem of these entrepreneurs is the fact that although they shift their production to countries like Albania, they do not create a long-term cooperation with these countries. Not even a distribution of technology or an increase of total productivity is noticed, even in those sectors where there has been a shift of production. The objective of this paper is to measure the convergence in the agricultural sector and the role that integration has played in the economic development of the country in order to give some modest suggestions for policy makers which may be necessary for designing development strategies in the future

Keywords: Convergence in Agriculture, Productivity Growth, Albania in EU Integration

\section{ALBANIAN PROBLEMATIC ISSUES OF AGRICULTURAL SECTOR FROM THE PERSPECTIVE OF EMPLOYMENT}

During the transition period, the agriculture sector in Albania has experienced a long phase of regression, along which it has played primarily a social function and not commercial objectives (Ancona, 2005). The lack of commercial goals and the limited agricultural area have created a lot of difficulties for farmers considering technological improvement, introducing 
new marketing techniques and realizing significant or standardized production volumes to inhibit the import of a major part of these products ${ }^{1}$.

According to a study of the Economist Intelligence Unit (EIU, 1999), agricultural land in Albania in August 31, 1992 was divided in over 460 thousand pieces with an average of about 0.2 hectare of arable land and 2.2 hectares of forests and pastures. This division, along with the lack of the arable land market and the ownership problems are the primary source of the lack of investment in technology in this sector and consequently the source of inefficiency and low productivity (Skreli and McCall, 2013).

It should be specified, however, that the deficiency problem of production in large quantities and fragmentation of land is not only a problem of Albania but also other of Balkan countries. According to the AgriPolicy.net, in Kosovo and Macedonia as well agricultural lands dimensions are small and do not exceed 3 hectares, only Croatia agricultural lands are slightly larger, i.e. about 4 hectares. However according to Volk the dimensions of agricultural lands are very small in the Balkans compared with the EU average.

According to the Volk study in EU, the enterprises with over 10 hectares of land constitute $10 \%$ of the total number of enterprises and $85 \%$ of the total arable terrain. While in some countries of the Balkan, enterprises with more than 10 hectares of land constitute $5 \%$ of the total number of enterprises and use $25 \%$ of the total area of arable land in Serbia, $41 \%$ in Montenegro and $52 \%$ in Croatia. While in Albania only $11 \%$ of agricultural enterprises have more than 2 hectares of land and none of the enterprises has more than 10 hectares of land (Volk, 2010).

According to Lampietti the size of agricultural enterprises in the Balkan countries is even smaller if it is taken into account EU countries like Italy, Greece and Spain in the 70s (Lampietti et. al., 2009). Regarding the contribution of agriculture to GDP according to the data of Table 1.1 it is noted that in Albania the share of agriculture sector is far more important. About $20 \%$ reaches this value during the last years; which if it is compared to the average of EU countries (more or less $2 \%$ i.e. 10 times smaller) remains very high, but also considering the Balkan countries such as Macedonia, Serbia or Montenegro who are similar countries to Albania where agricultural sector's share in GDP is half that of Albania.

According to the data of table 1.2 it can be noticed that the weight that agricultural sector occupies in total employment in Albania is relatively high. Although employment data are missing for Greece and Kosovo it can be said, however, that Albania is among the first countries of the Balkan Region with the highest weight of the agricultural sector in employment. So the impact of agriculture in our country is more stable in terms of both employment and its weight in GDP. But these two tables indicates at the same time that such a large weight in employment provides a relatively low contribution to GDP which from the other side is an indicator that the agricultural sector in Albania is very out of date and needs radical reforms to achieve the average of EU countries that Albania aspires. This fact argues and justifies the data of table 1.3 that Albania remains the last country in the Balkans in terms of productivity. This conclusion is credible even though the data of table 1.3 seems not very accurate.

Regarding our country it can be said that the lack of investment in technology in this sector and prolonged transition problems in Albania have made the sector inefficient and not attractive to stimulate the consolidation of establishing production lines.

From table 1.3 it is observed that after EU accession countries like Slovenia, Bulgaria and Romania appear to have a significant improvement in productivity. Given the current situation in Albania and the fact that Albania's entry into the EU seems distant, in such circumstances to achieve levels of EU in agriculture there is a lot of work ahead. Although it seems difficult it may be feasible taking into account the application of best practice of Slovenia and other countries part of EU. At the same time the relevant authorities of this sector should give technical assistance to entrepreneurs in this sector to promote the use of technology and to lower the gap of this sector with that of other countries and above all to make the sector more attractive from the standpoint of economic efficiency².

\footnotetext{
${ }^{1}$ R. Kola, E. Skreli, M.Osmani, A. Tanku, Farmers' characteristics as determinants of collective action: the case of Greenhouse Producers in Albania, NEW MEDIT nr. 2/2014, p.2

2 Botta, F. "The role of institutional factors for the development of agri-businesses" in: The Albanian food system, institutions, structures and policies by G. De Meo, Franco Angeli, Milan, 2004 pg.450
} 
Another possible way would be that of associations of different categories and the creation of cooperatives. This, according to the Bodini and Borzaga would be very important for entrepreneurs of the sector because it allows dimensional growth which from the other side enables an increase of market power, offering better conditions for both the purchase of inputs from the market and the sale of products. This increase of decision-making power in the market will have a positive impact on investment's growth in manufacturing technologies and those of conservation 1 .

An example of success can be considered the cooperatives in Trentino Alto Adige. This area is characterized by a very fragmented land like Albania and the costs of land plow are high. The creation of cooperatives not only enabled the survival of the agricultural sector but played an important role in the process of economic development of the territory.

Another case to be taken into consideration is the development of production lines by cooperatives in Uganda, NDAFCU, where initially farmers were unable to sell milk individually. Operating like a cooperative they managed to produce 30,000 liters of milk per day. This amount allowed local farmers to negotiate the sale price of milk and reached to invest in a manufactory of milk processing, enabling the production of different products, higher revenues and enhancing local development?2.

Another possibility would be the application of an integrated development model based on local comparative advantages, integrating all social and manufacturing components. Primary selection will be agriculture but the transformation lines will be encouraged shifting from the production of agricultural products in their processing, i.e. a shift in agro industry, thus promoting local agro tourism. This enables for different locations the opportunity not to be limited only to the production of grapes or milk, for example, but to transform them into wine or cheese. It can also be considered mass production of $100 \%$ organic products. Such a product would positively affect the exports even for the reason that such products are highly demanded in foreign markets. In Hungary the production of organic products in a poor area of fragmented agricultural terrain not only led to local development but also gave a positive contribution to trade balance since $91 \%$ of this production was exported.

\section{THE IMPACT OF AGRICULTURAL SECTOR ON IMPORT-EXPORT GROWTH}

During the transition period, Albania has experienced a continuous change of policy makers which all have had as common denominator, the priority of the agricultural sector considered by all as a strategic sector for economic growth in the country's future. In general, the agriculture and rural development remain two of the priorities of the integration process for both Albania and the countries of the Western Balkans ${ }^{3}$. The agriculture in Albania has had a chapter on its own even during the signing of the Pact of Stability and Association with the EU: Article 71, 76 and 79 of the SAP predicts that agriculture will be a priority for the strategic development plan of the country. The signed agreements for SAP and the openess of negotiations to become a EU candidate country, during 2007-2014, Albania needs to harmonize domestic legislation with that of the EU and Agricultural policy change by promoting the creation of land market. The latter would help to stimulate investments in this sector and to increase competitiveness and productivity. All these activities have as their primary objective, increasing agricultural production in order to meet domestic demand as well as the export of agricultural products in the midterm period ${ }^{4}$. Increasing exports is one of the primary indicators of competitiveness mentioning here the positive impact it has on employment.

If we refer to the export balance of agricultural products it can be observed that Albania has a dependent model on imports: in 2012 the export-import ratio in general was 1:1.67 (Ministry of Agriculture, 2013). As it can be noted in table 2.1 in 2008 this ratio was more or less 1: 8, and the trend recently has not experienced huge changes. This is proved in 2012 where the volume of imports of agricultural products was 875 million dollars while the export of these agricultural products was only 74 million dollars (MoA, 2013). A World Bank study shows that the scarcity of conservation and processing of

\footnotetext{
${ }^{1}$ C. Borzaga, R. Bodini, (2012). What to make of social innovation? Towards a framework for policy development. Euricse Working Paper, nr. 36, p. 8.

${ }^{2}$ C. Borzaga, R. Bodini, Cooperating to compete: the case of the Agricultural Cooperation. World Food Day, Wednesday, November 21 , 2012, Euricsce, $p$.

${ }^{3}$ D. Tomić, M. M. Ševarlić, N. Tandir, Agriculture of the countries of the western balkans and european integrations, Agroinform

Publishing House, Budapest, 2010, p.94-96

${ }^{4}$ http://www.bujgesia.gov.al/al/programi/zhvillimi-rural/bujgesia-dhe-zhvillimi-rural
} 
agricultural products structures is the reason why all agricultural products are salable only in areas close to production or wholesale traders, where the latter are king-maker in price's determination ${ }^{1}$. This phenomenon is widespread in Albania, given that the majority of traders require large amounts sinse there are no market rules, these traders often buy the products abroad leading domestic producers to bankruptcy.

\subsection{The trend of main agricultural products of Albania}

Regarding the cultivation of land in Albania, in the early ' 90 s after the agrarian reform, a major part of the farmers produced only for personal consumption. This led to a considerable increase of the sowing of cereals at about $40 \%$; this figure is similar to those of other Balkan countries. These cereals were used only for internal consumption and not for export.

While tabacco until the ' 90 s had a significant slice of export, after the agrarian reform the interess for this product fell sharply where only during the period 2000-2012 passed from 6,200 tons to 900 tons. Also the same trend had production of cotton or sugar-beet. Unlike tobacco, where the interest for its cultivation falls significantly, for fruits it is increasing year after year.

In the last decade the area cultivated with fruits has increased substantially, from 149,600 hectares in 2000 to 262,200 hectares in 2008 (AgriPolicy.Net, 2014). The same trend has had the cultivation of vegetables. The increased area of vegetables passed from 462 hectares that was in 2000 to 940 hectares in 2008 continuing the dimensional growth even in the coming years. During the last years in agriculture it is observed the usage of technology in production and investments in general. It is worth mentioning that the number of enterprises which used the greenhouses in Albania in 2000 was only 10 and in 2011 reached 102, while in 2012 greenhouse vegetable production reached 79,000 tons, or $9 \%$ of total output (MoA, 2013).

The significant growth of fruits and vegetables production is reached thanks to frequent interventions of the ministry of agriculture in the last decade. In fact the Ministry has introduced a range of practices of use to increase the production and the usage of technology as: friendly technologies, GAP best practice, CAP, common agricultural policy and the CMO, common market organization. According to the ministry all these practices will significantly increase the production and will lower their transportation costs (Ministry of Agriculture, Food and Consumer Protection 2014).

These interventions, appear to provide their effects in production productivity increase and the improvement of trade balance for agricultural products.

According to the ComTrade database (2013) for the period 2001-2011, the export of domestic vegetables increased by 9 times and the agricultural products export grew by $17 \%$ meanwhile in 2012 the export decreased by $1 \%$. An important contribution to a significantly increase of agricultural exports in 2012 gave olive and dry fruits production; the production of the latter only in 2013 increased by 10 times (MoAFCP, 2014). While the production of olives and olive oil in the same year was doubled.

Regarding the dried fruit and olives it can be said that their growth has come as a result of the above mentioned policies which not only have had undoubtedly a positive impact and significant contributions but also have provided the subsidies by the ministry launched in 2010 for the cultivation of these plants.

However, it can convincly be verified that the gap that exists between the Albanian agricultural sector and the other countries of EU and the Balkans is very high this due to the fact that Albanian agriculture is still with a deficit trade balance although this sector employees almost $43 \%$ of the the total labor force.

According to a recent study conducted on the analysis of trade balance of 98 products results that our country suffers a trade deficit for the major part of this category which in fact continues to grow every year. The only products that have a negative trade balance which is declining over the years are fruits and vegetables that have passed from $\$ 78.7$ million in 2009 to $\$ 61.3$ million in 2011 (Mitaj et. Al, 2014). So once again, it can be concluded that Albania poses serious problems of production structure in agriculture.

1 D. Soto, H. Gordon, P. Gedeshi, I. Sinoimeri, Poverty in Albania. A qualitative assessment, The World Bank, Washington DC, 2002, p. $11-12$ 


\section{CONCLUSIONS}

From the analysis of the agricultural sector in Albania, it is observed that Albania's agricultural land is very fragmented with an average of 0.2 hectare according to INSTAT data in 2000. This fragmentation of land from the preceding analysis is a consequence of 3 reasons: land ownership problems, agrarian reform of 1992 (Law 7501) and the lack of agricultural land market. These problems are the main source of the lack of investments in this sector. The lack of the latter is the primary cause of low productivity and productive inefficiency in this sector.

The analysis of some of the above indicators as contribution of agriculture to GDP and total employment of the country appears that this sector has a very low productivity not only in comparison with the average of the European Union but also compared to Balkan countries, which seems to be similar to Albania regarding the productive structures. Given these data it can be said that the agriculture sector in Albania has serious problems and there is a large gap compared with developed countries. For this reason, if it will be necessary that this sector serves in the future as a primary sector of Albania's economy there is a lot to be done. On one hand it is needed to consider the best practice in countries such as Slovenia or other countries of EU, and on the other hand it is necessary to orient investments in this sector, particularly in the use of technology in order to increase productivity and production. These investments should be investments associated with each other in the sense that an investment should boost other investments in order to not only increase production and productivity but also to promote the processing of these products, shifting from agriculture to agro-industry and agrotourism.

From the analysis of agricultural products import and export it was noticed that despite the fact that in this sector are employees of the labor force of our country, is has not been achieved yet sufficient production to be auto sufficient. So Albania has a huge trade deficit in this sector. In relation to this, institutions should make a detailed analysis of market demand for agricultural products, in order to orient the investments and subsidies in the production of those manufactures that currently have a deep trade deficit. This means that under the current situation faced in Albania it is important to initially produce for fulfilling domestic demand and after that the possibility to export is an option to be considered. Exporting is important because it is the most important indicator for the level of competitiveness but despite this, the primary objective in the short and medium term should be that of producing for domestic consumption.

\section{REFERENCES}

[1] Borzaga, C., Bodini, R., What to make of social innovation? Towards a framework for policy development, Euricse Working Paper, nr. 36, 12, 2012

[2] Botta, F. (2004). II ruolo dei fattori istituzionali per lo sviluppo delle imprese agroalimentari, in: II sistema agroalimentare albanese, istituzioni, strutture e politiche a cura di G. De Meo, FrancoAngeli, Milano

[3] De meo, G. (2004). II sistema agroalimentare albanese: istituzioni, strutture e politiche, Franco Angeli, Milano

[4] Kola, R., Skreli, E., Osmani, M., Tanku, A. Farmers' characteristics as determinants of collective action: the case of Greenhouse Producers in Albania, NEW MEDIT nr. 2/2014

[5] Lamnietti. J.. Luad. D. G. Van der Celen . P.. \& Branc.zik. A. (2009). The changing face of rural space: agriculture and rural development in the Western Balkans. World Bank Publications

[6] Mitai. A.. Muco. K.. Avdulai. J. (2014). Albania's Trade Specialization and its Economic Growth Perspective in the Future. European Journal of Sustainable Development, 3(3), 299-308

[7] Skreli. E.. \& McCalla, A. (2013). 9 Trade in Albania. Agricultural Markets in a Transitioning Economy: An Albanian Case Study

[8] Soto, D., Gordon, H., Gedeshi, P., Sinoimeri, I., Poverty in Albania. A qualitative assessment, The World Bank, Washington DC, 2002

[9] Tomić, D., Ševarlić, M. M., Tandir, N. Agriculture of the countries of the western balkans and european integrations, Agroinform Publishing House, Budapest, 2010, p. $94-96$

[10] Volk. T. (2010). Aariculture in the Western Balkan Countries, Leibniz Institute of Agricultural Development in Central and Eastern Europe, Leibniz 
Table 1.1: Agricultural contribution in country's GDP for the Balcan Region

\begin{tabular}{|c|c|c|c|c|c|c|}
\hline Year & Albania & Macedonia & Montenegro & Serbia & Slovenia & EU \\
\hline 1995 & 55.8 & 13.2 & 20.9 & 20.9 & 4.3 & 2.9 \\
\hline 1996 & 33.1 & 13.3 & 21.3 & 21.3 & 4 & 2.8 \\
\hline 1997 & 31.8 & 12.4 & 12.2 & 16.5 & 3.9 & 2.7 \\
\hline 1998 & 28.5 & 12.8 & 12.2 & 15.6 & 3.3 & 2.5 \\
\hline 1999 & 26.3 & 12.8 & 12.1 & 19 & 3.3 & 2.3 \\
\hline 2000 & 25.3 & 11.6 & 12.4 & 20 & 3 & 2.3 \\
\hline 2001 & 23.4 & 11.7 & 11.8 & 20 & 3.2 & 2.3 \\
\hline 2002 & 23.4 & 11.9 & 12.7 & 14.6 & 2.4 & 2.1 \\
\hline 2003 & 23.1 & 12.9 & 11.3 & 13.8 & 2.6 & 2.0 \\
\hline 2004 & 22.7 & 12.7 & 10.6 & 13.5 & 2.6 & 2.0 \\
\hline 2005 & 20.3 & 12.4 & 10.5 & 11.9 & 2.8 & 1.7 \\
\hline 2006 & 19.8 & 12.1 & 10 & 10.8 & 2.1 & 1.6 \\
\hline 2007 & 18.6 & 10.6 & 9.3 & 10 & 1.9 & 1.6 \\
\hline 2008 & 18.3 & 11.6 & 9.4 & 10.5 & 2 & 1.6 \\
\hline 2009 & 18.2 & 11.1 & 10 & 9.4 & 2 & 1.4 \\
\hline 2010 & 18.2 & 11.5 & 9.4 & 10 & 2.3 & 1.6 \\
\hline 2011 & 18.3 & 10.9 & 9.5 & 10.8 & 2.2 & 1.6 \\
\hline 2012 & 20 & 10.2 & 8.8 & 10.3 & 2.1 & 1.6 \\
\hline 2013 & 22.4 & 10.5 & 9.8 & n.d & & 1.7 \\
\hline
\end{tabular}

Source: Our calculations based on World Bank data, 2014

Table 1. 2 :Agriculture contribution in employment in \%

\begin{tabular}{|l|l|l|l|l|l|l|l|l|l|l|}
\hline Year & Albania & BH & Bulgaria & Croatia & Macedonia & Montenegro & Romania & Serbia & Slovenia & EU \\
\hline 1997 & 69.60 & & & 17.80 & & & 39.00 & & 12.00 & 8.50 \\
\hline 1998 & 70.80 & & & 16.70 & & & 40.00 & & 12.00 & 8.19 \\
\hline 1999 & 72.10 & & & 16.60 & & & 41.80 & & 10.80 & 7.91 \\
\hline 2000 & 71.80 & & 13.10 & 14.50 & & & 42.80 & & 9.50 & 7.77 \\
\hline 2001 & 72.20 & & 9.70 & 15.50 & & & 42.30 & & 9.80 & 7.55 \\
\hline 2002 & 57.70 & & 10.70 & 15.20 & 23.90 & & 36.40 & & 9.70 & 6.93 \\
\hline 2003 & 58.10 & & 11.10 & 16.80 & 22.00 & 9.00 & 35.70 & & 8.40 & 6.77 \\
\hline 2004 & 58.50 & & 10.60 & 16.40 & 16.80 & & 31.60 & 24.00 & 9.60 & 6.30 \\
\hline 2005 & 58.50 & & 8.90 & 17.30 & 19.50 & 8.60 & 32.10 & 23.30 & 8.80 & 6.16 \\
\hline 2006 & 58.00 & 20.60 & 8.10 & 14.20 & 20.10 & & 30.50 & 20.50 & 9.60 & 5.88 \\
\hline 2007 & 47.60 & 19.80 & 7.50 & 13.10 & 18.20 & 8.70 & 29.50 & 20.80 & 10.20 & 5.61 \\
\hline 2008 & 43.90 & 20.60 & 7.50 & 13.40 & 19.70 & 7.60 & 28.70 & 25.10 & 8.60 & 5.15 \\
\hline
\end{tabular}




\begin{tabular}{|l|l|l|l|l|l|l|l|l|l|l|}
\hline 2009 & 42.10 & 21.20 & 7.10 & 13.90 & & 6.50 & 29.10 & 24.00 & 9.10 & 5.61 \\
\hline 2010 & 41.50 & 19.70 & 6.80 & 14.90 & & 6.20 & 30.10 & 22.20 & 8.80 & 5.15 \\
\hline 2011 & & 19.60 & 6.80 & 15.40 & 18.70 & 5.60 & 28.60 & 21.20 & 8.60 & 4.99 \\
\hline 2012 & & 20.50 & 6.40 & 13.70 & 17.30 & 5.70 & 29.00 & 21.00 & 8.30 & 5.10 \\
\hline
\end{tabular}

Source: Our own calculations based on World Bank data, 2014

Table 1. 3: Agriculture added value per employee for Balcan countries (thousand dollars, constant prices (2005)

\begin{tabular}{|l|l|l|l|l|l|l|l|l|l|l|}
\hline Year & Albania & BH & Bulgaria & Croatia & Macedonia & Montenegro & Romania & Serbia & Slovenia & EU \\
\hline 1997 & 2,178 & & 7,452 & 7,961 & 4,983 & & 4,288 & & 33,351 & 12,7 \\
\hline 1998 & 2,321 & & 8,383 & 9,207 & 5,411 & & 4,104 & & 35,548 & 13,27 \\
\hline 1999 & 2,356 & & 9,83 & 9,575 & 5,703 & & 4,454 & & 38,248 & 14,23 \\
\hline 2000 & 2,486 & & 9,643 & 10,5 & 6,03 & & 3,839 & & 42,839 & 14,74 \\
\hline 2001 & 2,545 & & 9,69 & 11,64 & 5,534 & & 5,212 & & 47,894 & 15,11 \\
\hline 2002 & 2,573 & & 10,964 & 12,99 & 5,753 & & 5,563 & & 58,735 & 15,88 \\
\hline 2003 & 2,515 & & 11,679 & 12,9 & 6,289 & & 6,259 & & 49,189 & 15,86 \\
\hline 2004 & 2,593 & & 12,758 & 15,14 & 7,217 & & 8 & & 67,667 & 18,19 \\
\hline 2005 & 2,607 & 14 & 12,486 & 16,03 & 7,397 & & 7,094 & & 69,208 & 17,4 \\
\hline 2006 & 2,697 & & 12,773 & 18,61 & 7,926 & 4,396 & 7,57 & 3,576 & 74,899 & 17,74 \\
\hline 2007 & 2,769 & & 10,389 & 19,32 & 8,083 & 4,055 & 7,06 & 3,435 & 96,49 & 18,75 \\
\hline 2008 & 2,984 & & 14,577 & 21,84 & 8,998 & 4,73 & 9,006 & 3,895 & 96,969 & 20,31 \\
\hline 2009 & 3,066 & & 14,258 & 22,65 & 9,625 & 5,052 & 9,253 & 3,87 & 98,861 & 20,99 \\
\hline 2010 & 3,327 & & 14,207 & 22,91 & 10,841 & 5,24 & 9,289 & 4,304 & 115,57 & 20,85 \\
\hline 2011 & 3,515 & & 15,087 & 23,43 & 11,318 & 5,978 & 11,126 & 4,544 & 145,21 & 22,25 \\
\hline 2012 & 3,735 & & 15,031 & 21,64 & 11,134 & 5,649 & 9,117 & 3,938 & 133,66 & 21,92 \\
\hline
\end{tabular}

Source: Our own calculations based on World Bank data, 2014

Table 2. 1 Foreign exhanges and trade balance for agricultural products

\begin{tabular}{|l|l|l|l|l|l|}
\hline & Unit & 2005 & 2006 & 2007 & 2008 \\
\hline Trade volume of agricultural products & $\mathrm{m} \ln €$ & 428,0 & 502,0 & 734,8 & 651,3 \\
\hline Export volume of agricultural products & $\mathrm{m} \ln €$ & 46,4 & 53,8 & 75,5 & 60,1 \\
\hline Import volume of agricultural products & $\mathrm{m} \ln €$ & 381,6 & 448,2 & 659,3 & 591,2 \\
\hline Trade balance of agricultural products & $\mathrm{m} \ln €$ & $-335,2$ & $-394,3$ & $-583,8$ & $-531,1$ \\
\hline $\begin{array}{l}\text { \% of agricultural imports in relation to } \\
\text { country's total imports }\end{array}$ & $\%$ & 17,6 & 17,9 & 16,2 & 16,6 \\
\hline $\begin{array}{l}\text { \% of agricultural exports in relation to } \\
\text { country's total imports }\end{array}$ & $\%$ & 8,2 & 7,9 & 7,3 & 6,4 \\
\hline
\end{tabular}

Source: Our calculations according to AgriPolicy statistics Albania, 2014 